\title{
PRODUCTION OF 415-TON INGOTS FOR BACKUP ROLLS IN THE CONDITIONS OF PJSC "ENERGOMASHSPETSSTAL"
}

\author{
Maxim Victorovich Efimov ${ }^{a}$ \\ Anatoliy Danilovich Ryabtsev ${ }^{b}$ \\ Olexandr Andreevich Selyutin ${ }^{a}$ \\ Oleksandr Anatolievich Troyanskyy ${ }^{\text {b }}$ \\ Pavel Michaylovich Yavtushenko \\ Volodymyr Victorovich Pashynskyi ${ }^{\text {b }}$ \\ a PJSC «Energomashspetsstal», Kramatorsk, 84306, Ukraine \\ ${ }^{\mathrm{b}}$ State High Educational Institution «Donetsk National \\ Technical University», Donetsk, 83001, Ukraine
}

FIELD: Chemical Technology

DOI: 10.5937/vojtehg61-3873

ARTICLE TYPE: Original Scientific Paper

Abstract:

The paper gives the results of work on melting, pouring, forging and heat treatment of 415-ton $45 \mathrm{H} 3 \mathrm{M} 1 \mathrm{~F}$ steel ingots as semiproducts for manufacturing large backup rolls at the request of "Severstal» Company.

For the production of rollers, a new grade of steel based on $0.45 \% \mathrm{C}$ and $3 \% \mathrm{Cr}$, additionally alloyed by $\mathrm{Mo}$ and $\mathrm{V}$, was developed in PJSC «Energomashspetsstal» and applied in industry. Steel of bainite class provides the best combination of strength and plasticity properties.

Metal was prepared by melting 7 heats in arc steel-melting furnaces with the capacity of 100 and 50 tons with subsequent out-of-furnace treatment on ladle - furnace and ladle - degassing units. The pouring of steel was carried out from four steel-pouring ladles into a vertical mould under vacuum through a tundish ladle with the protection of stream by argon. The forging of ingots was conducted on the automated 150MN forging system. The obtained billets were exposed to primary heat treatment which consisted of heating for recrystallization, isothermal soaking, in order to provide the removal of residual stresses, additional dehydrogenization to give the material lower hardness and controlled cooling for the prevention of snowflake formation. Heating of ingots for forging and preliminary heat treatment was carried out in heat treatment furnaces with the carrying capacity of up to 500 tons. For the heat treatment of the backup roll, a horizontal sprayer unit was applied. The too- 
ling of the backup roll was executed on a lathe with one pace-plate and the final mechanical treatment was conducted on the machine-tool of Hercules NWD 1500×18000 CNC. Finished products with 225-ton mass of the following dimensions: a barrel with a diameter and a length of $2,360 \mathrm{~mm}$ and $4,800 \mathrm{~mm}$, respectively, at a general length of 10,650 $\mathrm{mm}$ were obtained.

Key words: ingot; 415 ton; technology; melting; pouring; casting; rollers; non-metallic inclusions.

\section{Introduction}

Currently, one of the conditions of the stable development of Cenergy is providing its new units, based on large-size products, with high reliability in operation. Therefore, modern power engineering requires more quality for original ingots (forgings) for these products. It is only possible to guarantee the high quality of forgings in the absence of metallurgical defects in the initial forging ingot. To do this, it is necessary to get pure on harmful impurities steel with dispersed and uniformly distributed non-metallic phases. The quality of parts, a complete resource of service characteristics, is formed during melting and casting. This may be provided by the application of modern metallurgical engineering and technology.

This approach is realized in the effort to provide a high level of metallurgical warranties of an ingot in one process module, the choice of the aggregate structure, which is universal. This approach to the production is implemented in the electric shop of PJSC «Energomashspetsstal» (PJSC "EMSS") during the melting of different grades of steel poured into large ingots weighing up to 415 tons for the production of turbine shafts, rolls for rolling mills and other large products (Jürgen, 2012), (Efimov, Eldarkhanov, 1998, p.359), (Dub, 1999, pp.22-30).

To implement this approach, it was necessary to transform the production of large steel ingots into a modern technological system in PJSC "EMSS" by gradual replacement of outdated equipment and the introduction of advanced technologies.

Before the start of reconstruction, the equipment list, the actual wear and space planning solutions of the electric steelmaking facility PJSC "EMSS", did not correspond to modern requirements, namely:

- classic technology of steel production could not provide the required level of steel product quality, as well as resource and energy savings;

- low productivity electric arc furnaces (EAF) of outdated design had physical wear of mechanical and electrical parts which was close to critical; 
- absence of facilities for a complex ladle treatment of metal hampered the prospect of raising the quality of steel.

Therefore, the modern multifunctional modular production scheme was taken as the basis for technical modernization of PJSC "EMSS", which is based on the application of integrated production units, allowing in sequence heating, refining, deoxidizing, alloying the steel in the ladle. These units include (Fig.1):

- melting of carbon or alloyed semi-product in EAF-50t and EAF$100 \mathrm{t}$ electric arc furnaces,, including the melting of charge materials, metal dephosphorization and its heating to a temperature of pouring;

- slag-free pouring of semi-product into the pouring ladle with filling to the last one de-oxidants and slag materials (if necessary, fulfillment of the operations of alloying metal is possible) in a combination with steel steering by inert gas by blowing elements mounted in the bottom of the ladle;

- secondary treatment technology in the ladle furnace, comprising:

- arc heating of melt in the ladle in order to compensate for the loss of heat during processing of the melt at the atmospheric pressure and under vacuum;

- a continuous steering of the melt during all process steps of the secondary treatment in order to equalize the steel temperature and intensify the mass transfer processes during desulfurization, diffusion and sediment reduction, alloying and degassing;

- injection under the slag of powder materials in a stream of gas through uncooled expended lance to adjust the carbon content;

- in-metal feeding of reagents in the form of a powder wire with a wire feeder for deep steel deoxidation and modification of non-metallic inclusions;

- vacuum processing of deoxidized metal under the refining slag in a chamber-type degasser, with the possibility of additional alloying and adjusting the chemical composition (about $60 \%$ of the steel subjected to evacuation to reduce the hydrogen content of less than 1.5-2.0 ppm and $30 \%$ - to decrease the content of non-metallic inclusions);

- vacuum oxygen decarburization;

- pouring of steel into molds (including under the vacuum in the vacuum chamber) to obtain the required quality of surface and internal structure of a large ingot while reducing the consumption of the metal as well as to achieve economies of molds, pallets and refractories;

- large ingot solidification and its cooling in the mold, stripping of ingot and transportation for later processing;

- forging of ingots at the forging press;

- machining on lathes. 


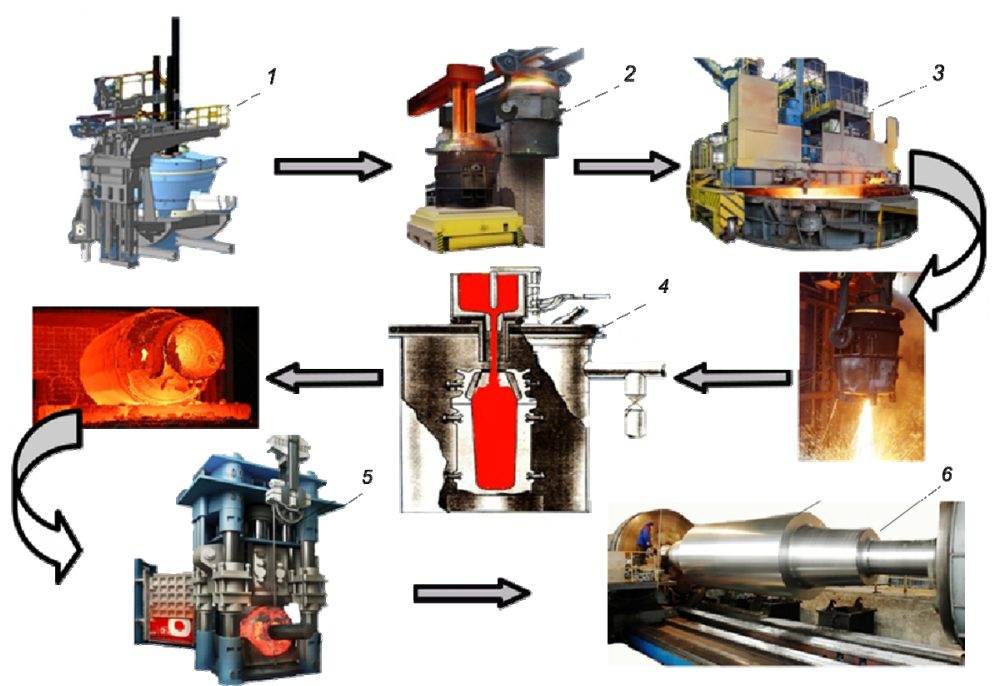

Fig. 1 - Scheme of technological manufacturing of a roll for a rolling mill from a forging ingot with a mass of 415 tons : 1 - electric arc furnace (EAF), 2 - ladle-furnace unit (LFU), 3 - degasser, 4 - vacuum pouring of ingot, 5 - forging press, 6 - roll for the rolling mill Slika 1 - Šema tehnologije proizvodnje valjka za valjaonicu od ingota mase 415 tona: 1 - elektrolučna peć (EAF), 2- peć s livnim kazanom (LFU), 3 -mašina za dezoksidizaciju 4 - vakuumsko ulivanje ingota, 5 - kovačka presa, 6 - valjak za valjaonicu

The first stage of the reconstruction has increased the level of quality of large ingots in accordance with international standards due to the commissioning of the secondary metallurgy complex (LFU - Chamber degasser VD / VOD).

The second stage included the construction and commissioning of the modern steel module based on a high-performance EAF-70 for the melting of the liquid semi-product, the ladle - furnace unit LFU and the chamber vacuum degasser. The new EAF replaces the existing melting units and provides an opportunity to work in harmony with two secondary metallurgy complexes.

\section{The technology of production of forging ingots weighing 415 tons}

The steel is melted in EAF 50t and EAF 100t electric arc steelmaking furnaces of traditional design, where deep dephosphorization occurs. After the mass fracture of phosphorus becomes not more than $0.004 \%$, oxidizing slag is removed. During tapping, deoxidizing is carried out by aluminum additions and heat insulation slag mixtures are introduced in the ladle. The collection of metal for 415-ton ingot pouring is realized by consequent tapping of heats from the EAF $50 \mathrm{t}$ furnace in the tran- 
sporting ladle and from the EAF100t - in the main ladle. For pouring a 415-ton ingot, four steel pouring ladles are used where the average weight of metal in a ladle is 120 ton.

The treatment of steel at the ladle-furnace unit is carried out under highly basic deoxidized refining slag in order to achieve deep desulfuration, compensation of heat losses during treatment, correction of chemical composition and providing of overheating of metal before degassing. The composition of the ladle treatment of metal in the electro steelmaking shop includes the ladle furnace and the vacuum vessel chamber.

It is necessary to consider a substantial increase in the residence time of melting in steel ladles. This is for two reasons:

1. Purity of steel for harmful impurities, dispersed and uniformly distributed structure of the non-metallic phase ensures rather long time of ladle treatment. The average duration of the treatment in the LFU is 141 and 88 minutes, and VD - 57 and 47 min, respectively, for the 100 and 50-ton ladles. The average processing time of melting in the aggregates of ladle metallurgy is about 198 and 135 minutes for the 100 and the 50-ton ladles, respectively.

2. Low productivity of arc steelmaking furnaces leads to the increase of storage time for casting of metal ingots weighing more than 100 tons. The average waiting time between the tapping and the start of treatment in the LFU is for the 100 and 50-ton steel ladle 84 and 51 minutes, and between the LFU and VD - 21 and 10 min, respectively. The overall average waiting time is 105 and 61 minutes for the 100 and the 50-ton ladles, respectively.

High velocity of desulfuration is provided by low oxidizing of melt from the first minutes of the treatment (Dyudkin, et al, 2003, p.62). The velocity and the degree of desulfuration of melt increase with the intensity of argon blowing through the aperture plugs (Farouk, et al, 2006, p.19). Parallel to heating and desulfuration of the steel, the correction of alloying elements content is performed. Ferroalloys are added at increasing argon consumption. The maximum portion of ferroalloys is not more than $200 \mathrm{~kg}$. After ferroalloys addition and (if necessary) carburizing, the averaging argon blowing is carried out for a period not less than 5 minutes; after that, a steel probe for chemical composition determination is picked up. The exposure of metal in the ladle from finishing the treatment in the LFU to the beginning of degassing usually does not exceed $30 \mathrm{~min}$.

After obtaining the necessary chemical composition and temperature, the steel pouring ladle with metal transferred for degassing. In order to provide good degassing, the refining slag is partially removed. Metal degassing is realized in two stages. In the first stage, the liquid metal in the ladle is subjected to the treatment in the degassing chamber. In the second phase, the finishing step is to pour metal into the mould placed in the vacuum chamber. The metal composition in the ladles after the vacuum treatment and in the ingot after pouring 45H3M1F steel is shown in Table 1. 
Table 1 - Chemical composition of $45 \mathrm{H} 3 \mathrm{M} 1 \mathrm{~F}$ steel in the ladle after the vacuum treatment and in the ingot after pouring

Tabela 1 - Hemijski sastav čelika 45H3M1F u delu za ulivanje nakon tretmana vakuumom i u ingotu posle ulivanja

\begin{tabular}{|c|c|c|c|c|c|c|c|c|c|c|c|c|c|c|}
\hline $\begin{array}{l}\text { Ladles/ } \\
\text { Ingot }\end{array}$ & \multicolumn{14}{|c|}{ Main elements content, \% } \\
\hline & C & $\mathrm{Si}$ & $\mathrm{Mn}$ & $\mathrm{P}$ & S & $\mathrm{Cr}$ & $\mathrm{Ni}$ & Mo & $\mathrm{Cu}$ & V & As & $\mathrm{Al}$ & Sn & $\mathrm{H} 2, \mathrm{ppm}$ \\
\hline Ladle № 1 & 0.47 & 0.25 & 0.58 & 0.009 & 0.003 & 3.42 & 0.18 & 0.67 & 0.08 & 0.13 & 0.004 & 0.006 & 0.004 & 0.8 \\
\hline Ladle № 2 & 0.44 & 0.31 & 0.64 & 0.006 & 0.005 & 3.35 & 0.19 & 0.64 & 0.08 & 0.12 & 0.005 & 0.004 & 0.004 & 1.3 \\
\hline Ladle №3 & 0.43 & 0.30 & 0.60 & 0.010 & 0.004 & 3.49 & 0.19 & 0.62 & 0.09 & 0.14 & 0.005 & 0.0058 & 0.004 & 0.5 \\
\hline Ladle № 4 & 0.37 & 0.38 & 0.72 & 0.012 & 0.012 & 3.43 & 0.14 & 0.62 & 0.07 & 0.12 & 0.005 & 0.005 & 0.005 & 0.5 \\
\hline Ingot & 0.43 & 0.31 & 0.64 & 0.009 & 0.006 & 3.42 & 0.18 & 0.64 & 0.08 & 0.13 & 0.005 & 0.006 & 0.004 & 0.87 \\
\hline
\end{tabular}

Pouring the metal after the treatment in the degasser is carried out in the vacuum in a special chamber as well. For the casting of 415 -ton ingots, a special mould was designed and manufactured. It provides a good formation and crystallization of ingots. Ingot pouring is performed from the top in the vacuum less than $1.5 \mathrm{mBar}$ through the intermediate stopper type ladle with mullite - corundum lining. Corundum barrels of 55 $\mathrm{mm}$ in diameter are used with a pouring velocity of, in this case, $7.0-7.5$ ton/min. The process of pouring is monitored through the special windows in the lid of the vacuum chamber. Casting rigging is heated before the assembling to a temperature above $100^{\circ} \mathrm{C}$. In the bottom plate of the mould, the cast metal insert is mounted. In order to decrease the liquation processes in the ingot, multipouring technology was used. It is based on the principle of different metal composition concerning $\mathrm{C}$ and Mo obtaining in different ladles. To decrease the liquation, a low content of such elements as $\mathrm{P}(0.009 \%), \mathrm{S}(0.005 \%)$ and $\mathrm{Cu}(0.19 \%)$ was obtained. After pouring, the top part of the ingot was warm-kept by additions of heat insulating mixtures in a quantity of $2 \mathrm{~kg}$ per ton of the ingot.

The crystallization of the steel ingot is the final step in the process of melting and casting, so the parametric data of crystallization is of considerable interest from the scientific and industrial point of view. These settings include the layer crystallization rate, the total time of ingot solidification and porosity. These parameters define the structural framework of the ingot and chemical homogeneity, and accordingly - and overall quality. For large ingots, accurate using of the data obtained in the laboratory or in the field study of ingots by small mass cannot be possible.

Therefore, a mathematical modeling of the crystallization of large ingots was conducted using the software package NovaSolid and NovaFlow (LVMFlow). The simulation allows studying the processes occurring in the metal at the fill out the form, the metal solidification and the emer- 
gence of shrinkage defects formation. The evaluation of the quality of ingots in the simulation was conducted by Niyama $(\mathrm{KH})$ criterion (Korotchenko, 2010, pp.43-47), (Berry, 2003).

The simulation results were used in the design of casting molds and for the estimation of the time required for ingot crystallization. After crystallization, during 65 hours of obtaining a surface temperature no lower than $600^{\circ} \mathrm{C}$, the ingot (Fig. 2) is transported to the forging-press shop for the subsequent processing.

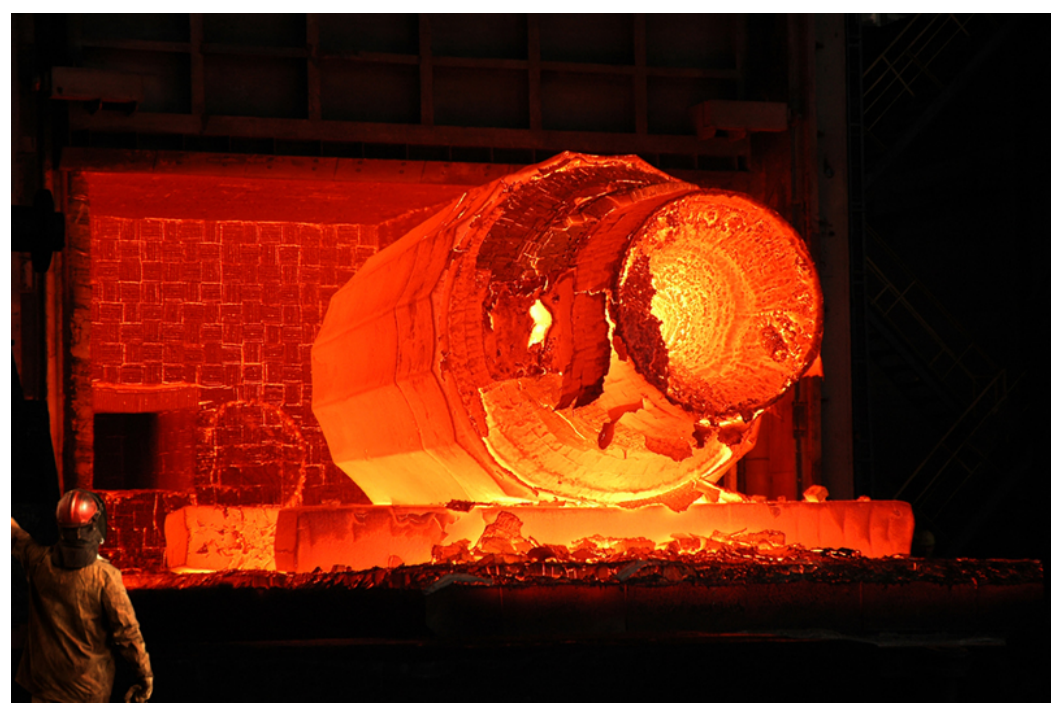

Fig. 2 - The ingot weighing 415 tons in the heat treatment furnace Slika 2 - Ingot težine 415 tona u peći za termičku obradu

Forging of ingots was conducted on the automated forging complex by a force of $150 \mathrm{MN}$. The obtained billets were exposed to the primary heat treatment which consisted of heating for recrystallization, isothermal soaking, removal of remaining stresses, additional dehydrogenization, giving to material lower hardness and controlled cooling for the prevention of snowflake formation. Heating of ingots for forging and preliminary heat treatment was carried out in the heat treatment furnaces with a carrying capacity up to 500 ton. For the heat treatment of backup rolls, the horizontal sprayer unit was used. Backup roll tooling was executed on a lathe with one pace-plate and the final mechanical treatment was conducted on the machine-tool of Hercules NWD $1500 \times 18000$ CNC . Finished products with 225-ton mass of the following dimensions: a barrel with a diameter and a length of $2,360 \mathrm{~mm}$ and $4,800 \mathrm{~mm}$, respectively, at a general length of $10,650 \mathrm{~mm}$, were obtained (Fig. 3). 


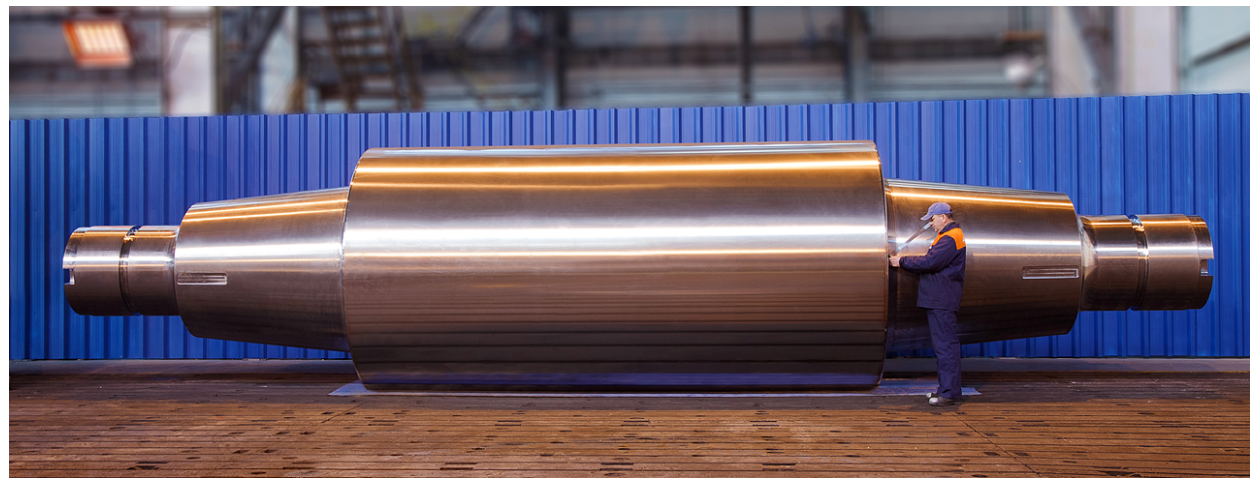

Fig. 3 - The rolling roller weighing 225 tons Slika 3 - Valjak težine 225 tona

\section{Investigation of non-metallic inclusions in large-mass ingots}

One of the important questions of technology is quality inspection. To do this, the laboratory was organized at the plant and all types of research were conduced: from the chemical analysis to non-destructive testing (Efimov, et al, 2012a, pp.3-7), (Efimov, et al, 2012b, p.152).

Taking into account a large size of ingots, three variants of sample selection were used:

- sampling of liquid metal at different steps of liquid metal treatment;

- sampling from specially designed points of ingots or forged semiproducts;

- sampling from the points where defects were found by ultrasonic inspection.

For the evaluation of inclusion content, the methods of optical microscopy and SEM microscopy were used. The scanning electron microscope was JSM-6490LV (JEOL, Japan).

Quantitative determination of contamination by non-metallic inclusions was conducted with the use of the "Videotest" software package («Metal 1.2» program module) in the automatic and manual modes.

The preliminary analysis has shown that the average concentration of $S$ and $P$ less than $0.005-0.007 \%$ and deep deoxidizing provide a very low volume of fraction of inclusion (less than $0.05 \%$ by vol.). Typical manganese sulphide of a spherical shape is shown in Fig. 4. Only single sulphides were detected, usually not in every field of view. The average size of such a type of inclusion did not exceed 10 microns. 
Another typical inclusion in metal of LMI is complex inclusion which consists of a combination of endogenous manganese sulphide with exogenous slag components (see Fig. 5). The local chemical composition in the points marked in the photos is shown in Table 2.

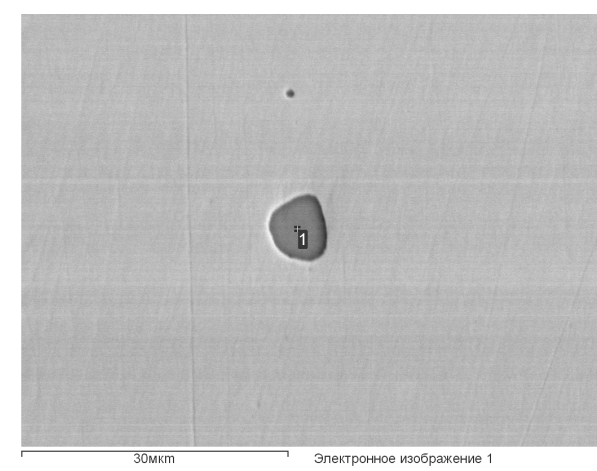

Fig. 4 - The general SEM view of manganese sulphide inclusion (1) in $26 \mathrm{NiCrMoV}$ steel

Slika 4 - Opšti izgled uključka mangan sulfida (1) u čelliku $26 \mathrm{NiCrMoV}$ dobijen metodom SEM

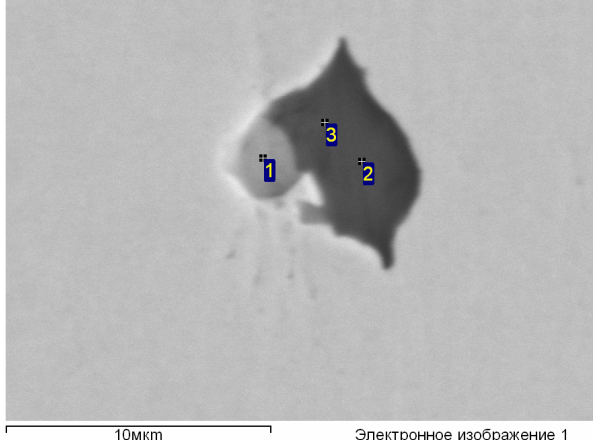

Fig. 5 - The general SEM view of the combined inclusion in $26 \mathrm{NiCrMoV}$ steel

Slika 5 - Opšti izgled kombinovanog uključka u čeliku $26 \mathrm{NiCrMoV}$ dobijen metodom SEM

Table 2 - Local chemical composition in points of inclusion (Fig. 2) \% by weight Tabela 2 - Hemijski sastav na mestima uključaka (SI.2) u težinskim procentima

\begin{tabular}{|l|l|l|l|l|l|l|l|}
\hline Point & $\mathrm{O}$ & $\mathrm{Mg}$ & $\mathrm{Al}$ & $\mathrm{Si}$ & $\mathrm{S}$ & $\mathrm{Ca}$ & $\mathrm{Mn}$ \\
\hline 1 & 2.35 & 0.03 & 0.98 & 0.49 & 26.51 & 1.65 & 47.4 \\
\hline 2 & 42.86 & 0.77 & 34.45 & 6.14 & 0.2 & 11.43 & 1.02 \\
\hline 3 & 39.86 & 0.48 & 19.28 & 10.7 & 0.69 & 17.52 & 1.84 \\
\hline
\end{tabular}

As we can see from Table 2, the inclusions in points 2 and 3 consist of oxides of $\mathrm{Al}, \mathrm{Si}$ and $\mathrm{Ca}$ and the shape of the inclusion is typical for a slag droplet. The above-mentioned image is typical for stable technology. At these conditions, the main fracture of inclusions was represented by relatively large inclusions with sporadic locations on micro-, meso-, and macro levels. The formation of such inclusions mostly deals with a sporadic deviation of the manufacturing process. The analysis has shown that most informative results were obtained from the samples selected on the basis of ultrasonic inspection results. They were selected from the points where reflections from defects were found. The statistical analysis has shown that in the practice of PJSC "Energomashspetsstal" this defect is very rarely formed. Another variant is a complex exogenous inclusion formed by products of refractory erosion and their interaction with slag droplets. A typical inclusion is shown in Fig. 6. 


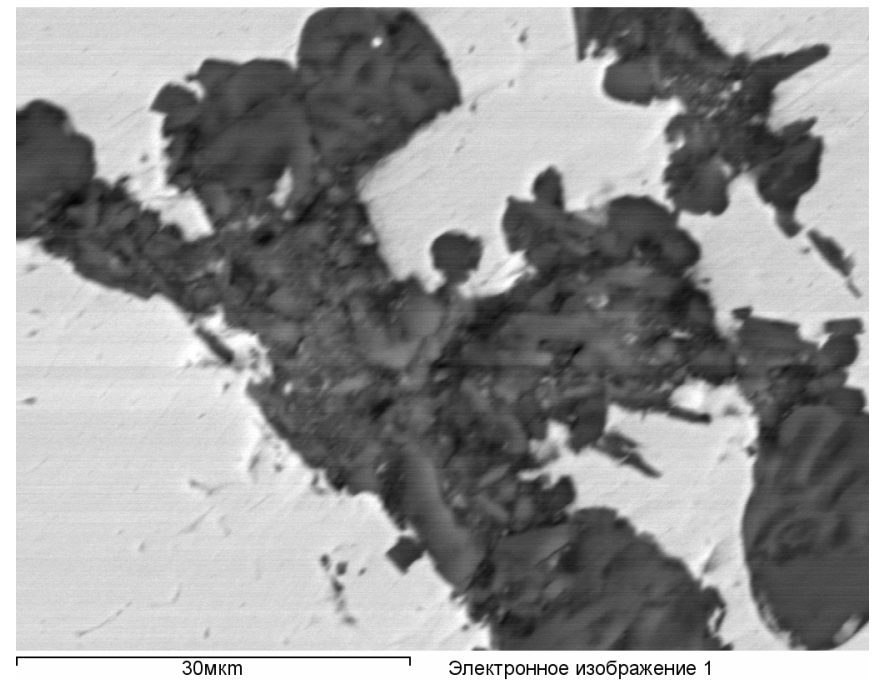

Fig. 6 - SEM image of the exogenous inclusion and the distribution of chemical elements in it

Slika 6 - SEM fotografija egzogenog uključka i distribucija hemijskih elemenata u njemu

This is the exogenous origin of the inclusion. In favour of this assumption, the form of the defects reveals their exogenous nature, namely the areas of irregular shape, filled with conglomerates of particles of different forms and compositions.

Another argument in behalf of the exogenous origin of inclusions is their spatial localization in the volume of the ingot. Endogenous inclusions are more characterised by enriching the axial area of the ingot, while in this case the majority of inclusions are concentrated relatively close to the surface (in the distance $70-120 \mathrm{~mm}$ ). It can probably be related to a large inclusion driving back and getting in the mould from the surface during rapid crystallization of the skin area with subsequent mechanical «fixing» between growing columnar crystals.

Due to the difference in surface tension on the boundary of nonmetallic inclusions with metal and slag, their coagulation with slag droplets takes place. But it is very important that, during the investigation, the presence of inclusions formed of pure slag particles has not been found. It means that the technology of tapping and pouring prevents the entering of large portions of slag in metal and only the interaction of slag droplets with the products of refractory erosion causes the formation of slag - inclusion aggregates. Therefore, in order to prevent the formation of such a type of defects, it is necessary to use the refractory with improved properties and increased resistance to the action of molten metal. 


\section{Conclusions}

1. The analysis showed that the production capacity of PJSC "Energomashspetsstal" after the reconstruction can solve actual scientific and engineering problems and implement modern approaches in production of high-quality large forging ingots for the production of turbine shafts and backup rolls for rolling mills.

2. The developed technology of melting, secondary treatment and casting of large forging ingots provides a high degree of purity of steel on compounds of sulphur and phosphorus and the oxides of aluminium and a mixture of complex oxides of type $(\mathrm{Al}, \mathrm{Ca}, \mathrm{Mg}, \mathrm{Si})_{\mathrm{m}} \mathrm{O}_{\mathrm{n}}$ become a basic non-metallic phase in large mass ingots. The most probable source of their appearance is the destruction of the refractory lining of furnaces and ladles; however, it is possible to assume that a part of them is formed in the process of deoxidizing and modifying of melt.

\section{References}

Berry, J.T. 2003. The effects of Applied Pressure During Feeding on the Fatigue Properties of Critical Cast Aluminum Alloy Components.Department of Mechanical Engineering Mississippi State University.

Dub, V.S., Makarychevf, E.V., \& Markov, I.I. 1999. Large ingot - current state amd future. Electrometallurgy,, 5, pp. 22-30.

Dyudkin, D.A., Bat, S.Y., \& Marintsev, S.N. 2003. Production of steel at ladle - furnace complex. Donetsk: South-West.Donetsk: South-West., p. 62.

Efimov, V.A., \& Eldarkhanov, A.S. 1998. Modern technologies of casting and crystallization of alloys.Machimebuilding., p. 359.

Efimov, M.V., Selyutin, A.A., Yavtushenko, P.M., Safonov, V.M., Troyanskyy, A.A., \& Ryabtsev, A.D. 2012. Modern technology of large ingots production for energy generation machinebuilding in conditions of JSC "Energomashspetsstal". Metal and casting of Ukraine, 9, pp. 3-7.

Efimov, M.V., Panov, V.V., Kolomoec, A.N., Lobanov, A.I., Pashynskyi, V.V., Snizko, O.A., \& Ryabtsev, A.D. 2012. Investigation of non-metallic inclusions in large-mass ingots, produced by PJSC «Energomashspetsstal».. In: Proceeding of the 5th International Congress on the Science and Technology of Steelmaking 2012 "ICS 2012", Dresden. , p. 152

Jürgen, A. 2012. Perspectives of ingot casting and forging industry in Europe and Worldwide. . In: Proceeding of the 1st International Conference on Ingot Casting, Rolling and Forging ICRF, Aachen, Germany. , pp. 3-7

Korotchenko, A.Y. 2010. Criteria of shrinkage porosity formation in ingots. Casting in Russia, 4, pp. 43-47.

Sidikki, F., Kodak, A.V., Kasyan, G.I., Yavtushenko, P.M., \& Popik, N.I. 2006. Modernization of out of furnace technology of steel treatment in ESMP JSC "MMZ "Istil (Ukraine)". Metal and casting of Ukraine, 1, p. 19. 


\section{PROIZVODNJA INGOTA OD 415 TONA ZA NOSEĆI VALJAK U ČELIČANI PJSC «ENERGOMASHSPETSSTAL»}

OBLAST: hemijske tehnologije

VRSTA ČLANKA: originalni naučni članak

\section{Sažetak:}

$U$ radu su prikazani rezultati rada na topljenju, livenju, kovanju $i$ termičkoj obradi ingota mase 415 tona od čelika 45H3M1F, kao poluproizvoda za proizvodnju velikih nosećih valjaka po narudžbini kompanije Severstal.

$U$ čeličani PJSC «Energomashspetsstal» razvijen je i primenjen u industriji novi tip čelika za proizvodnju valjaka, zasnovan na 0,45\% C i $3 \% \mathrm{Cr}$, i naknadno legiran s Mo i V. Čelik iz klase bainita obezbeđuje najbolju kombinaciju snage i plastičnosti.

Metal je pripremljen topljenjem 7 heats u lučnim pećima za topljenje čelika kapaciteta 100 i 50 tona i naknadno obrađen van peći u mašinama s kazanima za livenje i dezoksidatorima. Čelik se nalivao iz četiri livna kazana u vertikalni kalup pod vakuumom kroz uložno korito, dok je argon korišćen za zaštitu liva. Čelik je kovan na automatskom kovačkom sistemu snage 150 MN. Dobijeni bileti izlagani su primarnoj termičkoj obradi koja se sastojala od rekristalizacije, izotermalnog potapanja, za ukljanjanje zaostalih napona, dodatne dehidrogenizacije $i$ obezbeđivanje niže tvrdoće i kontrolisanog hlađenja da bi se sprečilo formiranje pahuljaste strukture. Zagrevanje ingota za kovanje i prelimiranu termičku obradu rađeno je u pećima za termičku obradu kapaciteta do 500 tona. Za termičku obradu nosećeg valjka korišćen je horizontalni raspršivač. Mašinska obrada nosećeg valjka rađena je na strugu s jednokoračnom pločom, a finalna mašinska obrada na alatnoj mašini Hercules NWD $1500 \times 18000$ CNC. Finalni proizvodi imali su masu od 225 tona i oblik valjka prečnika $2360 \mathrm{~mm}$ i dužine $4800 \mathrm{~mm}$ pri ukupnoj dužini od $10650 \mathrm{~mm}$.

Ključne reči: ingot, 415 tona, tehnologija, topljenje, nalivanje, livenje, valjci, nemetalni uključci

Paper received on: 09. 05. 2013.

Manuscript corrections submitted on: 13. 05. 2013.

Paper accepted for publishing on: 15. 05. 2013. 